ELORE (ISSN 1456-3010), vol. $16-1 / 2009$.

Julkaisija: Suomen Kansantietouden Tutkijain Seura ry.

[http://www.elore.fi/arkisto/1_09/ajank_salmi-niklander_01_09.pdf]

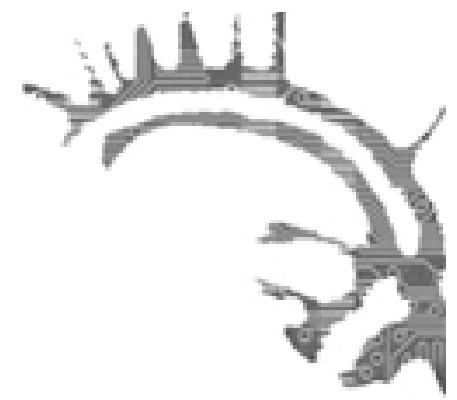

\title{
Ajankohtaista:
}

\section{KIRJALLISTUMINEN JA KANSANOMAINEN KIRJAKULTTUURI KESKUSTELUUN}

Society for the History of Authorship, Reading and Publishing -järjestön (SHARP) konferenssi Helsingissä 17.-21.8.2010

\section{$\underline{\text { Kirsti Salmi-Niklander }}$}

Suullisen ja kirjallisen kulttuurin vuorovaikutus, kirjoittamisen etnografia ja tekijyyden problematiikka ovat keskeisiä tutkimusteemoja monilla tämän päivän folkloristeilla. Näitä teemoja ja niihin liittyviä metodologisia kysymyksiä on erinomainen tilaisuus pohtia kirjahistorian SHARP-järjestön 18. konferenssissa, joka järjestetään Helsingissä 17.-21.8.2010. Konferenssin järjestämisestä kantaa päävastuun Helsingin yliopiston historian laitos. Mukana järjestelyissä ovat myös Svenska Litteratursällskapet, Suomalaisen Kirjallisuuden Seura, Pohjoismainen keskiajan tutkimuksen huippuyksikköhanke (NCMS) sekä Pohjoismaiden, Baltian ja Venäjän kirjahistorian tutkijoiden HIBOLIRE-verkosto.

Konferenssin pääteemana on "Book. Culture from Below"eli kansanihmisten ja alempien yhteiskuntaluokkien kirjakulttuuri. Tavoitteena on kyseenalaistaa kirjahistoriaan usein liitetty elitistinen leima ja korostaa kansanomaisen kirjakulttuurin omaehtoisuutta. Millaista on niiden ihmisten kirjakulttuuri, jotka eivät ole omistaneet yhtään kirjaa? Entä luku- ja kirjoitustaidottomien kirjakulttuuri? Konferenssissa pohditaan tekijyyden, kirjallistumisen ja (itse)opiskelun muotoja ja käytäntöjä. Keskeinen teema on myös suullisen perinteen ja kirjallisen kulttuurin vuorovaikutus.

Konferenssin keynote-puhujiksi ovat lupautuneet Ruth B. Bottigheimer ja Martyn Lyons. Ruth Bottigheimer (Stony Brook University, New York) on erittäin tunnettu ja arvostettu satututkija. Hänen näkemyksensä kansansatujen kirjallisesta alkuperästä (Bottigheimer 2002) herättivät kiihkeää väittelyä Tarton ISFNR- 
konferenssissa (The International Society for Folk Narrative Research) kesällä 2005. Tätä keskustelua jatketaan tuoreessa Marvels \& Tales -julkaisun numerossa (21 (1) 2007). Ruth Bottigheimerin luennon yhteyteen suunnitellaan satututkimuspaneelia, jossa pohdittaisiin suullisen ja kirjallisen kulttuurin jännitteitä ja vuorovaikutusta suhteessa satujen sepittämiseen, keräämiseen, julkaisemiseen ja lukemiseen.

Martyn Lyons (University of New South Wales, Australia) on tutkinut lukuja kirjoitustaidon yleistymistä ja vuorovaikutusta 1800-luvun Ranskassa. Hänellä on myös laajat kontaktit kirjoittamisen historian tutkijoihin eri Euroopan maissa. Lyonsin toimittamassa tuoreessa artikkelikokoelmassa (2007) on artikkeleita kansanomaisesta kirjoittamisen historiasta eri maissa, muun muassa Kaisa Kaurasen artikkeli 1800-luvun suomalaisista itseoppineista kirjoittajista. Uusimmassa monografiassaan Reading Culture and Writing Practices in Nineteenth-Century France Lyons (2008) tarkastelee luku- ja kirjoitustaidon omaksumista yksilön näkökulmasta nostaen esille omaelämäkerralliset lähteet ja arkikirjoittamisen muodot.

Kirjahistoria (book bistory) on syntynyt viime vuosikymmenien aikana historian- ja kirjallisuudentutkimuksen välimaastoon. Kirjojen elinkaaren ohella sen piirissä tutkitaan laajasti ottaen käsinkirjoitettujen ja painettujen mediumien, luomista, välittämistä ja käyttöä. SHARP-järjestö määrittelee tutkimusalueekseen tekijyyden, lukemisen ja julkaisemisen historian. Jotkut kirjahistorioitsijat (esimerkiksi Robert Darnton) määrittelevät tieteenalan mieluummin kommunikaatiohistoriaksi.

Itse olen kiinnostunut kirjahistoriasta käsinkirjoitettuja lehtiä käsittelevien tutkimusteni myötä ja olen osallistunut SHARP:in Euroopassa järjestettyihin konferensseihin yhteensä viisi kertaa. Kesällä 2000 Mainzissa pidetystä konferenssista kirjoitin innoittuneen raportin Eloreen (Salmi-Niklander 2001). Kaikki myöhemmät konferenssit eivät ole olleet aivan yhtä innostavia, ja olen havainnut tiettyä jämähtämistä anglosaksisiin aineistoihin ja tutkimusnäkökulmiin. Myös käsikirjoituskulttuurin tutkimus on jostain syystä jäänyt sivummalle, ja suurin osa esitelmistä on keskittynyt painetun kirjallisuuden tutkimukseen. Tämä trendi on kuitenkin muuttumassa jo Toronton SHARP-konferenssissa 23.-27.6.2009, jonka abstrakteja olen ollut arvioimassa. Vuosikonferenssien lisäksi SHARP on järjestänyt alueellisia ja temaattisia konferensseja. Kööpenhaminassa syyskuussa 2008 järjestetty alueellinen konferenssi avasi uusia kysymyksenasetteluja ja toi esille Pohjoismaiden ja Baltian maiden tuoretta tutkimusta, jossa käsitellään kirjallistumisen prosesseja suhteessa kulttuurisiin ja poliittisiin murroksiin. Tätä keskustelua on tarkoitus viedä eteenpäin Helsingin konferenssissa.

Konferenssin ohjelma on suunnitteilla. Call for papers alkaa syyskuussa ja päättyy marraskuun lopussa 2009. Konferenssin verkkosivut avataan kesällä 2009, mutta kiinnostuneet löytävät tietoa SHARP-järjestön verkkosivujen kautta: http://www. sharpweb.org/sharp2010.html. Konferenssista tiedotetaan myös Kansantieto-listalla. 


\section{Kirsti Salmi-NikLAnder}

\section{KiRJALlisuUS}

BOTTIGHEIMER, RUTH B. 2002: Fairy godfather: Straparola, Venice, and the fairy tale tradition. Philadelphia: University of Pennsylvania Press.

LYONS, MARTYN 2007 (toim.): Ordinary writings, personal narratives: writing practices in $19^{\text {th }}$ and early $20^{\text {th }}$-century Europe. Bern: Peter Lang.

LYONS, MARTYN 2008: Reading Culture and Writing Practices in Nineteenth-Century France. Toronto: University of Toronto Press.

SALMI-NIKLANDER, KIRSTI 2001: Kirjahistoriaa, mediahistoria, kommunikaatiohistoriaa? - Elore 1 (2001) [online] < http://cc.joensuu.fi/ loristi/1_01/sal101. $\mathrm{html}>[13.3 .2009]$

Filosofian tohtori Kirsti Salmi-Niklander on Helsingin yliopiston folkloristiikan dosentti ja SHARP 2010-konferenssin ohjelmatoimikunnan puheenjohtaja. 